\title{
Analysis of chromosomal aberrations in shoe workers exposed long term to benzene
}

\author{
Berrin Türkel, Unal Egeli
}

\begin{abstract}
Cytogenetic analysis of peripheral blood lymphocytes was used to compare 58 shoe workers (57 men and one woman) exposed to benzene and 20 subjects selected from the general population not exposed to particular mutagenic or carcinogenic agents (control group). Frequencies of damaged cells, including gaps, breaks, and rearrangements (acentric fragment, deletion, translocation) were scored for both groups. The incidence of chromosomal aberrations (particularly chromatid gaps and breaks) in the exposed group was significantly higher than in the control group. There were no effects of smoking and only breaks were affected by alcohol. Nor was there a significant relation between the working period in the group exposed to benzene and frequency of chromosomal aberrations.
\end{abstract}

(Occup Environ Med 1994;51:50-53)

Benzene and its derivates are important substances widely used in industry. Many workers are professionally exposed to the agents for a long time. Chronic benzene intoxication modulates immune responses and granulocyte enzyme systems, and leads to thrombocytopenia, leukopenia, anaemia, and pancytopenia; in extreme cases it can give rise to neoplastic diseases. ${ }^{1-5}$ The frequency of neoplasia in workers professionally exposed to benzene and its derivatives is significantly higher than in the unexposed population. ${ }^{6-8}$ Sasiadek et al showed that numerical or structural chromosomal aberrations were increased in workers exposed long term to benzene. ${ }^{9}$ Furthermore, they found that the chromosomal aberration ratios were increased by up to $55 \%$ in leukaemia that occurred after exposure to benzene. Sarto et al noted slight increases in chromosomal aberrations in lymphocyte cultures from 12 healthy workers in factories producing benzene, toluene, and xylene. These authors believed that this may have resulted from either recent exposure to low concentrations of benzene or to past exposures. ${ }^{10}$ Clare et al made a cytogenetic evaluation in peripheral blood lymphocyte cultures from 10 workers exposed to high concentrations of benzene as a result of a spillage of about 1200 gallons during the loading of a ship three months earlier. When they compared these chromosomal analyses with those from 11 normal men they found no significant differences between the two groups. ${ }^{11}$ Yardley-Jones et al found in their study made on 48 workers exposed to low concentration of benzene and 29 controls that chromosomal aberrations (particularly chromatid deletions and gaps) were slightly higher in the exposed group. ${ }^{12}$ Jablonicka $e t$ al, however, showed in their study on 66 workers exposed to benzene that although the frequency of chromosomal aberrations, including breaks and chromosomal exchanges, was slightly increased in the exposed group it was not significant. ${ }^{13}$ At the same time, they showed that benzene caused no health problem in these workers according to biochemical and haematological tests.

In our study, the chromosomal aberrations in shoe workers exposed to benzene and its derivatives because of their occupation were evaluated.

\section{Materials and methods}

The studies were carried out on peripheral blood lymphocytes of 58 shoe workers occupationally exposed to benzene and its derivatives for five to 50 years.

Twenty healthy subjects who were not exposed to benzene or any physical or chemical agents and living in the same area were taken as a control group. Both groups were interviewed about infectious diseases, drugs, and exposure to $x$ rays during the past two to three months before cytogenetic examination. It was found that $68 \%$ of shoe workers and $35 \%$ of the control group were smokers, and $39 \%$ of shoe workers and $5 \%$ of the control group drank alcohol. Blood samples were taken between May 1991 and July 1992. They were cultured at $37^{\circ} \mathrm{C}$ for 72 hours in medium containing $10 \%$ TC medium 199, $20 \%$ fetal calf serum, $10 \mu \mathrm{g} / \mathrm{ml}$ phytohaemagglutinin (PHAM), $100 \mu \mathrm{g} / \mathrm{ml}$ streptomycin, $60 \mu \mathrm{g} / \mathrm{ml}$ penicillin, and $70 \%$ sterilised distilled water. Colchicine was added to the cultures two hours before the harvest. Four chromosomal preparations were made from each subject according to a routine method. ${ }^{14}$ About 20 metaphases were analysed for numerical and structural aberrations under $1000 \times$ magnification with immersion oil. In the control group 435 metaphases and in shoe workers 1079 metaphases were worthy of examination.

STATISTICAL ANALYSIS

Chromosomal findings were compared between groups with the Duncan test. The
Department of
General Biology, The
Faculty of Sciences,
University of Uludag,
Gorukle-Bursa,
Turkey
B Türkel
U Egeli
Accepted 22 March 1993

Department of
General Biology, The
Faculty of Sciences,
University of Uludag,
Gorukle-Bursa,
Turkey
B Türkel
U Egeli
Accepted 22 March 1993 
working period and alcohol intake of the shoe workers and smoking habits of both groups were compared with chromosomal findings by regression analysis and Student's tests.

\section{Results}

Tables 1 and 2 show the results of cytogenetic analysis in non-exposed controls and benzene exposed shoe workers. Statistical analysis (including and excluding gaps) showed significant differences in frequencies of chromosomal aberrations between exposed and non-exposed groups (table 3 ). In the control group the mean frequency of cells with total chromosomal aberrations was $3.35 \%$. In the shoe workers, the frequency was $22 \cdot 2 \%$. Frequent gaps and breaks (particularly chromatid gaps and breaks) were found among total chromosomal abnormalities $(15 \cdot 7 \%$ and $4 \cdot 3 \%)$. Rearrangements such as acentric fragments, deletions, and translocations were found less often $(0 \cdot 6 \%)$. These abnormalities were not found in the control group. Only polyploidy was found as a numerical chromosomal abnormality (1.8\%) in the workers.

Table 4 shows the comparison of chromosomal findings with working period, smoking, and alcohol intake. No significant differences were found except for a relation between alcohol intake in shoe workers with breaks.

\section{Discussion}

In our study, workers occupationally exposed to benzene and its derivatives long term showed a significantly increased frequency of metaphase cells with structural chromosomal aberrations (including or excluding gaps) over that found in a control population. The most often observed aberrations were gaps and breaks. Generally gaps and breaks were the chromatid type. The rearrangement ratios such as acentric fragments, deletions and translocations were significantly increased in workers $v$ the control group. Acentric fragments were the most frequent rearrangements: deletions and translocations were rare.
Although numerical abnormalities were increased slightly in workers $v$ the control group the means did not differ significantly.

Previous studies on workers who have been exposed to benzene reported that chromosomal abnormalities were increased ${ }^{2911}$ and our study also seems convincing. Jablonicka et al, however, showed that frequency of chromosomal aberrations was not significantly increased in workers exposed to benzene long term when compared with a control group. ${ }^{13}$ The difference may be due to the concentration of benzene to which the workers in our study were exposed. When we compared all exposed workers and controls according to smoking and alcohol intake we found no significant differences in total numerical and structural chromosomal aberrations (table 4, p > 0.05). Also, we did not find any significant relation between the frequency of chromosomal aberrations and the working period.

Other investigators could not find any connection between chromosomal aberrations, frequency, age, sex, and working period, even though the frequency was higher in workers exposed to benzene than in control groups. ${ }^{21115}$ Yardley-Jones et al, however, found that chromosomal exchanges and the other chromosomal aberrations were increased in their study in older workers who were exposed to benzene long term. ${ }^{12}$ Aksoy et al found the appearance of different types of neoplasia as a result of long term exposure to benzene. ${ }^{2}$ Furthermore, Sasiadek et al showed that there was an increase in abnormal chromosomal aberrations in leukaemia that occurred in workers exposed to benzene. ${ }^{9}$

There is a relation between many malignancies and chromosomal abnormalities. ${ }^{16}$ Chromosomal damage has an important role in the activation of proto-oncogenes and their interaction plays an indirect part in the formation of malignancy. ${ }^{16}$ Although the metabolism and toxicity of benzene in the organism are known, the mechanism of neoplastic cell transformation induced by benzene has not yet been elucidated. Activation of the tyrosine kinase group of oncogenes may play a key

Table 1 Percentage of cells with chromosomal damage in peripheral blood lymphocyte cultures from control subjects

\begin{tabular}{|c|c|c|c|c|c|c|c|c|c|c|}
\hline \multirow[b]{2}{*}{ Subject } & \multirow[b]{2}{*}{$\begin{array}{l}\text { Age } \\
(y)\end{array}$} & \multirow{2}{*}{$\begin{array}{l}\text { Alcohol } \\
\text { intake }\end{array}$} & \multirow{2}{*}{$\begin{array}{l}\text { Daily } \\
\text { smoking } \\
\text { (pack) }\end{array}$} & \multirow{2}{*}{$\begin{array}{l}\text { No of } \\
\text { metaphases } \\
\text { analysed }\end{array}$} & \multirow[b]{2}{*}{ Gaps } & \multirow[b]{2}{*}{ Breaks } & \multirow[b]{2}{*}{$\begin{array}{l}\text { Rearrange- } \\
\text { ments }\end{array}$} & \multirow[b]{2}{*}{ Polyploidy } & \multicolumn{2}{|l|}{ Total } \\
\hline & & & & & & & & & +gaps & -gaps \\
\hline 1 & 24 & - & 0 & 20 & 0.00 & 0.00 & 0.00 & 0.00 & 0.00 & 0.00 \\
\hline 2 & 3 & - & 0 & 30 & 0.00 & .00 & 0. & 0.00 & 0.00 & 0.00 \\
\hline 3 & 23 & - & 0 & 20 & 0.00 & 0.00 & 0.00 & 0.00 & 0.00 & 0.00 \\
\hline 4 & 26 & + & 1 & 30 & 0.00 & 0.00 & 0.00 & 0.00 & 0.00 & 0.00 \\
\hline 5 & 28 & - & 0 & 20 & 5 & 0.00 & 0.00 & 0.00 & & 0.00 \\
\hline 6 & 31 & - & 0.5 & 20 & 0.00 & 0.00 & 0.00 & 0.00 & 0.00 & 0.00 \\
\hline 7 & 23 & - & 0 & 25 & 0.00 & 0.00 & 0.00 & 0.00 & 0.00 & 0.00 \\
\hline 8 & 24 & - & 0 & 20 & 5 & 0.00 & 0.00 & 0.00 & 5 & 0.00 \\
\hline 9 & 28 & - & 0 & 20 & 0.00 & 0.00 & 0.00 & 0.00 & 0.00 & 0.00 \\
\hline 10 & 24 & - & 1 & 20 & 5 & 0.00 & 0.00 & 0.00 & 0.00 & 0.00 \\
\hline 11 & 27 & - & 0 & 20 & 0.00 & 0.00 & 0.00 & 0.00 & 0.00 & 0.00 \\
\hline 12 & 29 & - & 0 & 25 & 8 & 0.00 & 0.00 & 0.00 & & 0.00 \\
\hline 13 & 29 & - & 0.5 & 20 & 0.00 & 0.00 & 0.00 & 0.00 & 0.00 & 0.00 \\
\hline 14 & 23 & - & 0.1 & 20 & 10 & 5 & 0.00 & 5 & 20 & 10 \\
\hline 15 & 36 & - & 0.33 & 20 & 5 & $0 \cdot 00$ & 0.00 & 0.00 & 5 & 0.00 \\
\hline 16 & 36 & - & 0.75 & 25 & 4 & 0.00 & 0.00 & 0.00 & 4 & 0.00 \\
\hline 17 & 32 & - & 0 & 20 & 5 & 0.00 & 0.00 & 5 & 10 & 5 \\
\hline 18 & 31 & - & 0 & 20 & 0.00 & 0.00 & 0.00 & 0.00 & 0.00 & 0.00 \\
\hline 19 & 35 & - & 0 & 20 & 0.00 & 0.00 & 0.00 & 0.00 & 0.00 & 0.00 \\
\hline & 29 & - & 0 & 20 & & 0.00 & 0.00 & 0.00 & & 0.00 \\
\hline Mean(SD) & $28.5(4.8)$ & & & $21 \cdot 8(3 \cdot 4)$ & $2 \cdot 6(3 \cdot 2)$ & $0.25(0.1)$ & $0(0 \cdot 0)$ & $0.5(1.5)$ & $3 \cdot 4(5)$ & $0.75(2.4)$ \\
\hline
\end{tabular}


Table 2 Percentage of cells with chromosomal damage in peripheral blood lymphocyte cultures from benzene exposed shoe workers

\begin{tabular}{|c|c|c|c|c|c|c|c|c|c|c|c|}
\hline \multirow[b]{2}{*}{ Subject } & \multirow[b]{2}{*}{ Age (y) } & \multirow{2}{*}{$\begin{array}{l}\text { Period of } \\
\text { exposure } \\
\text { (y) }\end{array}$} & \multirow{2}{*}{$\begin{array}{l}\text { Alcohol } \\
\text { intake }\end{array}$} & \multirow{2}{*}{$\begin{array}{l}\text { Daily } \\
\text { smoking } \\
\text { (packet) }\end{array}$} & \multirow{2}{*}{$\begin{array}{l}\text { No of } \\
\text { metaphases } \\
\text { analysed }\end{array}$} & \multirow[b]{2}{*}{ Gaps } & \multirow[b]{2}{*}{ Breaks } & \multirow{2}{*}{$\begin{array}{l}\text { Rearrange- } \\
\text { ments }\end{array}$} & \multirow[b]{2}{*}{ Polyploidy } & \multicolumn{2}{|l|}{ Total } \\
\hline & & & & & & & & & & +gaps & - gaps \\
\hline 1 & 26 & 16 & - & 1 & 18 & $11 \cdot 11$ & $11 \cdot 11$ & 0.00 & $11 \cdot 11$ & 33.33 & $22 \cdot 22$ \\
\hline 2 & 37 & 29 & - & 2 & 17 & 17.64 & 0.00 & 0.00 & 0.00 & $17 \cdot 64$ & 0.00 \\
\hline 3 & 44 & 35 & - & 0.5 & 17 & 29.41 & 0.00 & 0.00 & 5.88 & $35 \cdot 29$ & $5 \cdot 88$ \\
\hline 4 & 24 & 12 & + & 1 & 17 & 17.64 & 0.00 & 0.00 & 0.00 & 17.64 & 0.00 \\
\hline $5(F)$ & 43 & 11 & - & 0 & 10 & 20 & 0.00 & 0.00 & 0.00 & 20 & 0.00 \\
\hline 6 & 41 & 29 & - & 1 & 17 & $11 \cdot 76$ & $11 \cdot 76$ & $5 \cdot 88$ & 0.00 & $29 \cdot 41$ & $17 \cdot 65$ \\
\hline 7 & 41 & 28 & - & 1 & 19 & 21.05 & 0.00 & 0.00 & 0.00 & 21.05 & 0.00 \\
\hline 8 & 29 & 19 & - & 1 & 23 & 13.04 & 8.69 & $4 \cdot 34$ & 0.00 & 26.08 & 13.04 \\
\hline 9 & 40 & 30 & - & 0 & 13 & 23.07 & 0.00 & 0.00 & 0.00 & 23.07 & 0.00 \\
\hline 10 & 34 & 21 & - & 0 & 13 & $15 \cdot 38$ & 0.00 & 0.00 & 0.00 & $15 \cdot 38$ & 0.00 \\
\hline 11 & 54 & 44 & + & 0 & 15 & 20 & 0.00 & 0.00 & 0.00 & 20 & 0.00 \\
\hline 12 & 43 & 28 & - & 1 & 25 & 12 & 4 & 0.00 & 0.00 & 16 & 4 \\
\hline 13 & 52 & 30 & - & 0 & 20 & 10 & 0.00 & 0.00 & 0.00 & 10 & 0.00 \\
\hline 14 & 39 & 20 & - & 0 & 17 & 11.76 & 0.00 & $5 \cdot 88$ & 0.00 & $17 \cdot 64$ & 5.88 \\
\hline 15 & 22 & 11 & + & 1 & 37 & 13.51 & $2 \cdot 70$ & 0.00 & 0.00 & $16 \cdot 21$ & $2 \cdot 70$ \\
\hline 16 & 33 & 20 & + & 1 & 13 & 0.00 & $7 \cdot 69$ & 0.00 & 0.00 & 7.69 & 7.69 \\
\hline 17 & 24 & 10 & + & 0.5 & 43 & $18 \cdot 60$ & $9 \cdot 30$ & 0.00 & 4.65 & 32.55 & 13.95 \\
\hline 18 & 47 & 37 & - & 1 & 10 & 20 & 0.00 & 0.00 & 0.00 & 20 & 0.00 \\
\hline 19 & 60 & 50 & + & 0 & 10 & 10 & 20 & 0.00 & 0.00 & 30 & 20 \\
\hline 20 & 24 & 11 & + & 1 & 22 & 9.09 & 9.09 & 0.00 & 0.00 & $18 \cdot 18$ & 9.09 \\
\hline 21 & 32 & 20 & + & 2 & 14 & 0.00 & $14 \cdot 28$ & 0.00 & $7 \cdot 14$ & $21 \cdot 42$ & $21 \cdot 42$ \\
\hline 22 & 24 & 12 & - & 0 & 9 & $11 \cdot 11$ & 0.00 & 0.00 & $22 \cdot 22$ & 33.33 & $22 \cdot 22$ \\
\hline 23 & 44 & 35 & + & 0 & 23 & 8.69 & $4 \cdot 34$ & 0.00 & 0.00 & 13.04 & $4 \cdot 34$ \\
\hline 24 & 34 & 23 & + & 0 & 19 & 10.52 & 10.52 & 0.00 & $5 \cdot 26$ & $26 \cdot 31$ & 15.79 \\
\hline 25 & 42 & 25 & - & 0.3 & 17 & $11 \cdot 76$ & $5 \cdot 88$ & $5 \cdot 88$ & 5.88 & 29.41 & $17 \cdot 65$ \\
\hline 26 & 38 & 11 & + & 1 & 17 & 11.76 & $11 \cdot 76$ & 0.00 & 0.00 & 23.52 & 11.76 \\
\hline 27 & 33 & 24 & + & 1 & 21 & $9 \cdot 52$ & $9 \cdot 52$ & 0.00 & 9.52 & $28 \cdot 57$ & 19.05 \\
\hline 28 & 30 & 17 & + & 1.5 & 15 & 13.33 & $6 \cdot 66$ & 0.00 & 0.00 & 20 & 6.66 \\
\hline 29 & 69 & 50 & - & 0 & 30 & 13.33 & 6.66 & 3.33 & 0.00 & $23 \cdot 33$ & 10 \\
\hline 30 & 31 & 22 & + & 1.5 & 15 & 6.66 & $6 \cdot 66$ & 0.00 & 0.00 & 13.33 & 6.66 \\
\hline 31 & 31 & 12 & + & 2 & 20 & 10 & 10 & 0.00 & 0.00 & 20 & 10 \\
\hline 32 & 42 & 31 & + & $1 \cdot 3$ & 20 & 10 & 0.00 & 0.00 & 0.00 & 10 & 0.00 \\
\hline 33 & 22 & 8 & + & 0 & 17 & $11 \cdot 76$ & 5.88 & 0.00 & 0.00 & $17 \cdot 64$ & $5 \cdot 88$ \\
\hline 34 & 22 & 11 & + & 1 & 26 & $15 \cdot 38$ & 3.84 & 0.00 & 0.00 & $19 \cdot 23$ & 3.84 \\
\hline 35 & 43 & 30 & - & 0 & 8 & 12.50 & 0.00 & $12 \cdot 50$ & 0.00 & 25 & 12.5 \\
\hline 36 & 27 & 14 & + & 0.5 & 13 & 7.69 & 0.00 & 0.00 & 7.69 & $15 \cdot 38$ & 7.69 \\
\hline 37 & 42 & 22 & + & 1.7 & 12 & $8 \cdot 33$ & $8 \cdot 33$ & 0.00 & $8 \cdot 33$ & & 16.67 \\
\hline 38 & 46 & 38 & - & 0.5 & 11 & $18 \cdot 18$ & 9.09 & 0.00 & 0.00 & $27 \cdot 27$ & 9.09 \\
\hline 39 & 48 & 38 & + & $1 \cdot 7$ & 21 & $14 \cdot 28$ & $4 \cdot 76$ & $4 \cdot 76$ & $4 \cdot 76$ & $28 \cdot 57$ & $14 \cdot 29$ \\
\hline 40 & 27 & 7 & + & 0 & 10 & 20 & 0.00 & 0.00 & 0.00 & & 0.00 \\
\hline 41 & 27 & 10 & - & 1 & 24 & $8 \cdot 33$ & $4 \cdot 16$ & 0.00 & 0.00 & $12 \cdot 5$ & $4 \cdot 16$ \\
\hline 42 & 28 & 13 & - & 0 & 20 & 20 & 10 & 0.00 & 0.00 & 30 & \\
\hline 43 & 47 & 35 & - & 0.8 & 15 & 13.33 & 0.00 & 6.66 & 0.00 & 20 & 6.66 \\
\hline 44 & 46 & 32 & - & 3 & 18 & 5.55 & 5.55 & 0.00 & 0.00 & $11 \cdot 11$ & 5.55 \\
\hline 45 & 39 & 25 & - & 1 & 26 & $19 \cdot 23$ & 0.00 & 0.00 & $3 \cdot 84$ & 23.07 & 3.84 \\
\hline 46 & 23 & 10 & - & 1 & 13 & $15 \cdot 38$ & $7 \cdot 69$ & 7.69 & 0.00 & $30 \cdot 76$ & $15 \cdot 38$ \\
\hline 47 & 24 & 5 & - & 1 & 11 & $27 \cdot 27$ & 0.00 & 0.00 & 0.00 & $27 \cdot 27$ & 0.00 \\
\hline 48 & 46 & 30 & - & 1 & 21 & 19.04 & 0.00 & 0.00 & 0.00 & 19.04 & 0.00 \\
\hline 49 & 45 & 30 & - & 1.5 & 15 & 33.33 & 0.00 & 0.00 & 0.00 & 33.33 & 0.00 \\
\hline 50 & 41 & 30 & - & 1 & 29 & $24 \cdot 13$ & 0.00 & $3 \cdot 44$ & 3.44 & 31.03 & 6.9 \\
\hline 51 & 24 & 8 & - & 0 & 30 & 16.66 & 0.00 & 0.00 & 0.00 & 16.66 & 0.00 \\
\hline 52 & 25 & 8 & - & 0 & 10 & 30 & 0.00 & 0.00 & 0.00 & 30 & 0.00 \\
\hline 53 & 61 & 40 & - & 1 & 20 & 25 & 0.00 & 0.00 & 0.00 & & 0.00 \\
\hline 54 & 39 & 25 & - & 2 & 26 & $19 \cdot 23$ & $3 \cdot 84$ & 0.00 & 0.00 & 23.07 & 3.84 \\
\hline 55 & 24 & 10 & - & 1 & 21 & $23 \cdot 80$ & 0.00 & 0.00 & 0.00 & $23 \cdot 80$ & 0.00 \\
\hline 56 & 45 & 30 & - & 0.8 & 30 & 13.33 & 0.00 & 3.33 & 0.00 & 16.66 & 3.33 \\
\hline 57 & 50 & 35 & + & $1 \cdot 5$ & 25 & 20 & 0.00 & 0.00 & 4 & 24 & \\
\hline 58 & 40 & 30 & - & 0 & 11 & 9.09 & 9.09 & 0.00 & 0.00 & $18 \cdot 18$ & 9.09 \\
\hline $\operatorname{Mean}(S D)$ & $37 \cdot 2 \pm 10 \cdot 9$ & $23 \cdot 2 \pm 11 \cdot 4$ & & $0.8 \pm 0.7$ & $18 \cdot 6 \pm 7 \cdot 1$ & $15 \pm 6.8$ & $4 \cdot 2 \pm 4 \cdot 8$ & $1 \cdot 39 \pm 3 \cdot 3$ & $1.8 \pm 3.9$ & $22 \cdot 1 \pm 6 \cdot 7$ & $7 \cdot 08 \pm 6 \cdot 84$ \\
\hline
\end{tabular}

part in the neoplastic transformation of cells. ${ }^{5}$ 1718 Benzene may affect the tyrosine kinase groups of oncogenes by causing chromosomal damage and as a result of this malignancy may arise. No direct relation could be found, however, in the previous studies or in our study, between the increase of chromosomal abnormalities and cancer in workers exposed to benzene long term. Although chromosomal abnormalities were high in our study, no symptom described in the interview related to malignancy, symptoms tended to relate to stomach, skin, and respiratory complaints. This situation would suggest that the development of cancer is a multistep process and the increase in chromosomal abnormalities only is insufficient in this development. We think that the reason for the high frequency of chromosomal abnormalities in our study may be because of high concentrations of benzene in the working environment.
In Turkey, although the acceptable maximum allowable concentration (MAC) in the working environment is $20 \mathrm{ppm}$, Aksoy pointed out that the maximum benzene value was between 210 to $610 \mathrm{ppm}$ during working hours in workplaces in Istanbul. ${ }^{19}$ This may be because of the content of benzene (more than $1 \%$ ) and hexane (more than $44 \%$ ) in adhesives. Also, unhealthy working conditions such as narrow working places with insufficient ventilation and a lack of hygiene could be other factors. In our country, moves are being made to limit the content of hexane to $55 \mathrm{ppm}$ and to decrease the MAC from 20 ppm to $1 \mathrm{ppm}$.

In conclusion, chromosomal abnormalities are increased in the workers exposed to benzene long-term in our study. It is recommended that the MAC concentration should be decreased from $20 \mathrm{ppm}$ to $1 \mathrm{ppm}$ and working conditions should be improved. 
Table 3 Comparison of chromosomal data of shoe workers and controls

\begin{tabular}{|c|c|c|c|c|c|}
\hline \multirow[b]{2}{*}{ Compared criteria } & \multicolumn{2}{|l|}{ Means } & \multirow[b]{2}{*}{$F t_{(a=0.05)}$} & \multirow[b]{2}{*}{$F_{h}$} & \multirow[b]{2}{*}{ p Value } \\
\hline & $\begin{array}{l}\text { Shoe workers } \\
(n=58)\end{array}$ & $\begin{array}{l}\text { Controls } \\
(n=20)\end{array}$ & & & \\
\hline $\begin{array}{l}\text { Break } \\
\text { Gap } \\
\text { Rearrangements } \\
\text { Polyploidy } \\
\text { Total: }\end{array}$ & $\begin{array}{r}4 \cdot 187 \\
15 \cdot 044 \\
1 \cdot 399 \\
1 \cdot 788\end{array}$ & $\begin{array}{l}0 \cdot 25 \\
2 \cdot 6 \\
0 \\
0 \cdot 5\end{array}$ & $\begin{array}{l}3 \cdot 13 \\
3 \cdot 13 \\
3 \cdot 13 \\
3 \cdot 13\end{array}$ & $\begin{array}{c}12.94 \\
61.51 \\
3.69 \\
2.016\end{array}$ & $\begin{array}{l}\star \star<0.05 \\
<0.05 \\
<0.05 \\
\text { NS }\end{array}$ \\
\hline $\begin{array}{l}\text { + gap } \\
\text { - gap }\end{array}$ & $\begin{array}{r}22 \cdot 121 \\
7 \cdot 075\end{array}$ & $\begin{array}{l}3.35 \\
0.75\end{array}$ & $\begin{array}{l}3 \cdot 13 \\
3 \cdot 13\end{array}$ & $\begin{array}{l}130 \cdot 4 \\
16 \cdot 255\end{array}$ & $\begin{array}{l}<0.05 \\
<0.05\end{array}$ \\
\hline
\end{tabular}

Table 4 Comparison of chromosomal findings with working period and alcohol intake of shoe workers and smoking habits of both groups by regression analysis and Student's $t$ test

\begin{tabular}{|c|c|c|c|c|}
\hline 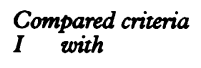 & $I I$ & $\begin{array}{l}\text { Correlation coefficient } \\
\text { (r) }\end{array}$ & $t_{h}$ & p Value \\
\hline Working period & $\begin{array}{l}\text { Break } \\
\text { Gap } \\
\text { Rearrangement } \\
\text { Polyploidy } \\
\text { Total }\end{array}$ & $\begin{array}{l}0 \cdot 006 \\
0 \\
0 \cdot 0389 \\
0 \\
0\end{array}$ & $\begin{array}{l}0.006 \\
0 \\
0.0943 \\
0 \\
0\end{array}$ & $\begin{array}{l}\text { NS } \\
\text { NS } \\
\text { NS } \\
\text { NS } \\
\text { NS }\end{array}$ \\
\hline Alcohol intake & $\begin{array}{l}\text { Break } \\
\text { Gap } \\
\text { Rearrangement } \\
\text { Polyploidy } \\
\text { Total }\end{array}$ & $\begin{array}{l}0.263 \\
-0.405 \\
-0.1107 \\
0.0638 \\
0\end{array}$ & $\begin{array}{l}2.04 \\
-3.33 \\
-0.834 \\
0.478 \\
0\end{array}$ & $\begin{array}{l}\star \star<0.05 \\
\text { NS } \\
\text { NS } \\
\text { NS } \\
\text { NS }\end{array}$ \\
\hline Smoking & $\begin{array}{l}\text { Break } \\
\text { Gap } \\
\text { Rearrangement } \\
\text { Polyploidy } \\
\text { Total }\end{array}$ & $\begin{array}{l}0.149 \\
-0.168 \\
-0.067 \\
-0 \\
0\end{array}$ & $\begin{array}{l}1 \cdot 1298 \\
-1 \cdot 281 \\
-0 \cdot 502 \\
-0 \cdot 185 \\
0\end{array}$ & $\begin{array}{l}\text { NS } \\
\text { NS } \\
\text { NS } \\
\text { NS }\end{array}$ \\
\hline
\end{tabular}

1 Aksoy M, Dincol $\mathrm{K}$, et al. Details of blood changes in 32 patients with pancytopenia associated with long term exposure to benzene. $\mathrm{Br} \mathcal{F}$ Ind Med 1972;29:56-64.

2 Aksoy M, Erdem S, et al. Combination of genetic factors and chronic exposure in the etiology of leukemia. Hum Hered 1976;26:149-53.

3 Smolik R, Grzybek-Hryncewicz K, Lange A. Serum complement level in workers exposed to benzene, toluene plement level in workers exposed to benzene,

4 Dean BJ. Genetic toxicology of benzene, toluene, xylene and phenols. Mutat Res 1978;47:75-97.

5 Croncite EP. Chemical leukogenesis: benzene as a model. Semin Hematol 1987;24:2-11.

6 Honeycombe JR. The effects of busulphan on the chromosomes of normal human lymphocytes. Mutat Res 1983;57:35-49.

7 Yin SN, Tain FD, et al. Leukemia in benzene workers; a retrospective cohort study. $\mathrm{Br} F$ Ind Med 1987;44: 124-8.

8 Rinsky RAD, Alexander MS, et al. Benzene and leukemia. N Engl f Med 1987;316:1044-50.

9 Sasiadek M, Sagielski J, Smolik R. Localization of breakpoints in the karyotype of workers professionaly exposed to benzene. Mutat Res 1989;224:235-40.

10 Sarto F, Cominato I, Pinton AM, et al. A cytogenetic study on workers exposed to low concentrations of benzene. Carcinogenesis 1984;5:827-32.
11 Clare MG, Yardley-Jones A, Maclean AC, Dean BJ. Chromosome analysis from peripheral blood lymphocytes of workers after an acute exposure to benzene. $\mathrm{Br}$ f Ind Med 1984;41:249-53.

12 Yardley-Jones A, Anderson D, Lovel DP, Jenkinson PC Analysis of chromosomal aberration in workers exposed Analysis of chromosomal aberration in workers exposed

13 Jablonicka A, Vargova M, Karelova J. Cytogenetic analysis of peripheral blood lymphocytes in workers exposed to of peripheral blood lymphocytes in workers exposed to
benzene. $\mathcal{F} \mathrm{Hyg}$ Epidemiol Microbiol Immunol 1987;8:

14 Yunis J. Human chromosome methodology. 2nd ed. New York; Academic Press, 1974.

15 Sasiadek $M$. Zmiany chromosomalne obserwowane $u$ pracownicow przewlekle narazonych na benzen $i$ jego pochodne. Pol Tyg Lek 1984;39:40-1.

16 Bloomfield CD, Trent JM, Van Den Berghe D. Report of the committee on structural chromosomal changes in neoplasia, human gene mapping 9 (1987): ninth international workshop on human gene mapping. Cytogenet Cell Genet 1987;46:344-6.

17 Kalf GF. Recent advances in the metabolism and toxicity of benzene. Crit Rev Toxicol 1987;18:141-59.

18 Synder R, Jowa I, et al. Formation of reactive metabolites from benzene. Arch Toxicol 1987;60:61-4.

19 Aksoy M, Hematotoxicity and carcinogenicity of benzene. Environ Health Perspect 1989;82:193-7. 